\title{
Inequality and the Emergence of Vigilante Organizations: The Case of Mexican Autodefensas
}

\author{
Version accepted at Comparative Political Studies \\ 2016 \\ Brian J. Phillips \\ Centro de Investigación y Docencia Económicas (CIDE) \\ brian.phillips@cide.edu
}

\begin{abstract}
What explains the emergence of vigilante organizations? Throughout the world, vigilantes emerge to illegally punish perceived criminals, often leading to serious consequences. However, the literature presents partial and conflicting explanations for this phenomenon. This article argues that local economic inequality creates a situation ripe for vigilante organizations. Inequality creates demand for vigilantism because poorer citizens feel relatively deprived of security compared to wealthier neighbors who have advantages regarding private and public security. Additionally, inequality suggests a patron-andworker distribution of labor, and this is ideal for organizing a particular type of group, the patron-funded vigilante group. Empirical tests use original data on the 2013 wave of Mexican vigilante organizations, present in 13 of Mexico's 32 federal entities. Municipallevel income inequality is robustly associated with organized vigilantism. Less support is found for competing explanations.
\end{abstract}

I thank Regina Bateson, Jorge Chabat, Ana Carolina Garriga, Edgar Guerra, María Inclán, Tom Long, Michael Weintraub, and Daniel Zizumbo for valuable comments on earlier drafts, or related discussions. Previous versions were presented at CIDE, the 2014 meeting of the Peace Science Society (International), and the 2015 meeting of the Midwest Political Science Association. Participants provided helpful comments. I thank David Blanc Murguía, Constanza Castro Orduña, Sandra Juan Delgado, Andrés García Hugues, and Andrea Marin Serrano for research assistance. Replication data is available at the CPS website and at the author's website: https://sites.google.com/site/brianjphillips/ 


\section{Introduction}

What explains the emergence of vigilante organizations? Vigilantism is important to understand because it represents a challenge to rule of law and governance. In a number of countries, it appears to be increasing (Ungar, 2007; Honorine, 2013). Some research suggests vigilantism can reduce crime (Osorio, Schubiger, \& Weintraub, 2015). However, vigilante organizations are often responsible for serious human rights violations, and their behavior can lead to tit-for-tat escalations of violence (Abrahams, 1987, p. 186; Romero, 2003; Conaway, 2004). Furthermore, these groups sometimes turn into other types of nefarious actors, such as drug-traffickers or extortionists. In spite these reasons to understand vigilantism, the literature offers contrasting explanations for this behavior (Baker, 2004; Handy, 2004; Godoy, 2006; Bateson, 2013). There have been few attempts to rigorously evaluate claims for why vigilantism occurs.

This article argues that local economic inequality plays an important role in explaining why some areas experience vigilantism and others do not. Economic inequality implies security inequality, and two related mechanisms can produce organized vigilantism. First, there is a greater demand for organized vigilantism in unequal localities because lower-income citizens feel relatively insecure compared to wealthier neighbors, who have greater access to private and public security. Vigilantism is one way poorer citizens can mitigate the security gap, the relative deprivation of security. Second, economic inequality provides a distribution of labor that is useful for organizing a particular type of vigilante group. When wealthier citizens seek out private security, one option is mobilizing their own vigilante group. This has occurred as business owners, for example, form an ad hoc force to protect their economic interests. However, regardless of the funding or organizational 
structure of vigilantism, economic inequality and the security inequality it implies should lead to more organized vigilantism.

The argument is tested quantitatively with original data on the autodefensa (selfdefense) organizations that appeared throughout in Mexico in 2013. The subnational comparative approach offers a number of advantages over other types of studies (Snyder, 2001), and Mexico is an important and interesting case. After years of violence connected to drug-trafficking organizations in the country, a wave of organized vigilantism occurred, with groups forming in more than 70 municipalities, in 13 of Mexico's 32 federal entities. Why did groups form in certain areas, but not others? Interestingly - and as is the case in other countries - the vigilante organizations did not appear in the parts of the country with the highest crime, or in the areas with the weakest state presence. The Mexico case shares a number of attributes with other developing countries experiencing higher levels of crime, so it can inform the study of other cases as well.

The topics of how citizens react to crime, and economic inequality, speak to several important political science debates. Crime and crime victimization affect political participation in meaningful ways (Bateson, 2012; Trelles \& Carreras, 2012). Assuming that vigilantism is a type of political participation, how should crime affect the likelihood of the appearance of vigilante organizations? Regarding economic inequality, this is an important causal factor for many outcomes of interest, such as democratization (Boix, 2003; Ansell \& Samuels, 2010) and taxation (Mares \& Queralt, 2015). However, inequality has fallen out of favor as an explanation for violence such as civil war, as it is usually not correlated with conflict onset in large-n studies (Fearon \& Laitin, 2003; Collier, Hoeffler, \& Rohner, 
2009). ${ }^{1}$ Could inequality contribute to other types of organized violence, such as vigilantism?

The next section defines the concept of vigilante organizations, and discusses two sub-categories. The third section reviews the literature on vigilantism. The fourth section presents the argument. The fifth section discusses vigilantism in Mexico, offering anecdotal evidence for the argument. The sixth section introduces original data on vigilante organizations in Mexico in 2013, and describes empirical tests. Results suggest municipallevel income inequality is robustly associated with vigilantism. Other factors such as crime rates, government capacity, and indigenous population are not as consistently related to organized vigilantism.

\section{What are vigilante organizations?}

There are a range of types of vigilante actors, which can be characterized by the number of persons involved and their level of organization. On one end of the spectrum are individual vigilantes. Further along on the spectrum are relatively hastily-organized groups, such as lynch mobs or crowds that assemble for one act of street justice. Next along the spectrum are vigilante organizations, collectives of individuals more persistent and structured than mobs. These groups are the focus of the present study.

It is difficult to know for certain, but some scholars argue that organized vigilantism is more common than individual vigilantism (Burrows, 1976, p. 274; Abrahams, 1987, p. 179). Regarding vigilante mobs, scholars have sought to understand this type of behavior, which continues to occur throughout the world (Handy, 2004; Godoy, 2006). However, mass and relatively random violence likely has some different causes and consequences

\footnotetext{
${ }^{1}$ There are some exception, such as Cederman, Gleditsch, \& Buhaug (2013).
} 
than more organized and sustained vigilante behavior - the actions of what this article refers to as vigilante organizations.

I define vigilante organizations as sustained associations of private citizens voluntarily seeking to illegally control crime or other social infractions in a planned, premeditated way, involving force or the threat of force. ${ }^{2}$ The inclusion of "sustained," as well as "planned" and "premeditated," in this definition seeks to distinguish relatively formal organizations from random mobs. Formal organizations tend to have names and a definable membership (Wilson, 1973, p. 31), and these might be additional ways to demarcate these types of groups. This separation is useful because, as noted above, it is likely that very different factors explain one afternoon of street violence as opposed to a systematic campaign waged by a named group.

Within the category of vigilante organizations, there are further distinctions that can be made. Reviewing the literature, there are two basic ideal-types of vigilante organizations that appear: grassroots community groups, and patron-funded groups. In reality, some groups are hybrids between these varieties. For example, some groups led by land-owning ranchers in Michoacán, as discussed below, also had community support and received donations. However, these two sub-categories are ideal types that can be used to illustrate funding mechanisms and other dynamics.

Grassroots community groups might essentially be self-funded, or receive donations from their neighbors. Members probably carry their personal weapons, and patrol in their free time. This was the case with some groups in recent years in southern Mexico, in areas

\footnotetext{
${ }^{2}$ This definition is an effort to craft a succinct definition from the features Johnston (1996) mentions as necessary for a criminological definition of vigilantism. I add "sustained" to disqualify spontaneous groups engaging in one act, and also add "illegally" because I consider legal and non-legal measures conceptually distinct.
} 
such as Guerrero (Fausset, 2014; Macías, 2014). Some groups in Mexico have received donations from migrants in the United States (Yagoub, 2014), probably former community members, and this would be consistent with the group type. Grassroots community vigilante organizations, in various forms, have appeared in many contexts. The Sungusungu in Tanzania, formed to combat cattle theft, received donations from their neighbors (Abraham, 1987, p. 182). In South Africa, the group People Against Drugs and Gangsterism started in 1996 as a grassroots vigilante group, although its motives and membership changed with time.

Patron-funded groups, as the name implies, have another source of support. This could be fairly benign, such as a community-oriented group with a sponsor who is concerned about the community and asks no favors in return. However, what seems to be more common are patron-funded groups that exist primarily to protect the patron's business interests, potentially including workers - instead of an entire community at large. ${ }^{3}$ This suggests patron-funded vigilantes differ from strictly grassroots community groups in terms of their loyalty and goals. Examples include the various autodefensa groups formed in Colombia in the 1980s to protect landowners and drug traffickers from guerrillas, as well as groups organized by business owners in the Mexican city of Juárez more recently. Some groups organized by Michoacán ranchers arguably belong in this category as well. In Honduras, business leaders have been accused of hiring former security personnel for

\footnotetext{
${ }^{3}$ Some readers might think of these groups as militias, as militias often involve some form of patronage system. However, theoretical and popular work on vigilante groups includes both grassroots community types groups and patron-funded groups as "vigilante groups." The important commonality they share is the primary motive of illegally substituting for the state to provide security from (other) criminals. Regarding militias, the literature tends to define these groups broadly: armed, organized groups that are not a part of the state security forces (Carey et al., 2013). Technically, all vigilante organizations meet this definition of militia. See also Schuberth (2015).
} 
vigilante justice (U.S. Department of State, 2005), which is consistent with the idea of patron-funded vigilantism. In Nigeria, the Bakassi Boys at least started out as this type of group, since business owners supported them financially (Ibrahim, 2005). ${ }^{4}$ Overall, vigilante organizations are an important type of actor, and two important sub-types are the grassroots community group and the patron-funded group.

\section{What explains vigilantism?}

The most common explanation for vigilantism is weak government in the face of crime. ${ }^{5}$ Baker $(2004$, p. 167) summarizes the argument, for at least one region: "Together, the perceptions of failing state police and rising crime have created a situation today where a plethora of non-state policing groups has emerged across [Africa]." The same arguments have been used to explain vigilance committees of the $19^{\text {th }}$ century U.S. West (Arellano, 2012). Some analysts suggest these factors explain vigilantism in Mexico as well (Martínez, 2013). Mexico certainly has challenges regarding its criminal justice institutions (Uildriks and Tello Peón, 2010). Research suggests that Mexicans are more likely to express support for vigilantism if they do not trust local government institutions (Rojo Mendoza, 2015). However, supporting the idea of vigilantism is not the same as taking up arms. Furthermore, descriptive data on Mexico suggest that vigilante organizations did not form in the municipalities with the weakest governments, or the highest crime rates.

Similarly, in many countries with relatively fragile institutions, vigilantism has not emerged in the areas with the highest crime (Ungar, 2007, p. 24; Godoy, 2006, p. 18).

\footnotetext{
${ }^{4}$ The group eventually was funded by state governments, which raises questions about its status as a vigilante group.

${ }^{5}$ Crime and government weakness, or at least perceptions thereof, are not independent. For example, crime victimization seems to lead to less faith in the government (Carreras, 2013).
} 
An additional explanation for vigilantism is cultural. Handy $(2004,560)$ argues that lynchings in Guatemala are a response to an "alien" judicial system forced upon indigenous people. Some scholars studying vigilantism in Africa suggest that it is a return to indigenous customs (Gore and Pratten, 2003; Omeje, 2005). Omeje, discussing vigilantes in Nigeria, argues that colonial powers, and later Western countries, had imposed notions of governance and security "diametrically opposed" to traditional views (Omeje, 2005, pp. 7274). As a reaction, citizens formed vigilante groups. If cultural or indigenous explanations applied to Mexico, we might expect to see vigilantism mostly in areas with high percentages of indigenous citizens, but this does not appear to be the case.

Another set of studies emphasizes how civil wars can shape vigilante behavior. Bateson's (2013) work is innovative for considering how past civil war dynamics explain variation in vigilantism. Bateson argues that violence in the Guatemalan civil war that ended in 1996, among other factors, shapes how Guatemalans would later respond to insecurity. ${ }^{6}$ Quantitative tests suggest that a locality's history of wartime violence is associated with vigilantism. The study considers alternative explanations, including inequality, which is not related to vigilantism in the Guatemalan case. Other research looks at vigilantism during civil war. Studies of autodefensas in Colombia explain how these groups formed during civil war as a way for landowners and other elites to protect their property from insurgents (e.g., Romero, 2003). Kowalewski's (1990) research on the antiMaoist "vigilante counterinsurgency" in the Philippines showed that these groups often

\footnotetext{
${ }^{6}$ Bateson (2013) does not argue that civil war is a necessary condition for vigilantism. Although her theory's causal mechanisms are explained in terms of civil war and wartime violence (pp. 19-20), it is also argued that the theory can be applied to non-post-conflict settings (p. 291). The three ways wartime experiences affects vigilantism are via affecting threat perceptions, strategic understandings of violence and punishment, and institutional legacies.
} 
violated human rights. These civil war cases involve decades of political violence, and models explaining vigilantism in these contexts might need to be adjusted to explain vigilantism in the face of criminal violence, such as that which has occurred in Mexico. ${ }^{7}$

An alternate and less common set of explanations involves economic inequality, and related concepts such as neoliberalism and globalization (Pratten and Sen, 2008). Analysis of the Mexican case argues that increased free trade in the 1990s adversely affected many communities, which in turn led to increased vigilantism (Fuentes Díaz and Paleta Pérez, 2015, pp. 174-175). Regarding inequality in particular, a study of vigilantism and other private security in Latin America argues that inequality is one explanatory factor among several (Ungar, 2007). Research on Nigerian vigilantes suggests that inequality is part of the causal story in that country, but in a highly contextualized manner (Smith, 2004). University students in secret societies were suspected of perpetrating crimes, so people from lower classes formed vigilante groups in part to respond to these crimes of the elite. In a different context, Godoy (2006) blames neoliberalism, along with decades of state violence, for the increase in lynchings in Guatemala since the 1990s. A common theme in this work is that neoliberalism and inequality matter because they have affected justice, or perceptions of justice, in important ways.

These arguments involving inequality raise a number of questions. Is it only the broad phenomenon of neoliberalism that leads to organized vigilantism, or does economic inequality in particular play a direct role? To what extent does the effect of inequality depend on unique local factors, such as university student crimes (in the Nigerian case above) or recent state violence (in Guatemala)? Is there a more general relationship

\footnotetext{
${ }^{7}$ On similarities and differences between political and criminal violence, see Kalyvas (2015) and Phillips (2015).
} 
between inequality and vigilantism? In the next section I build on this work to argue that local economic inequality contributes to the emergence of vigilante organizations.

\section{Economic inequality, security inequality, and organized vigilantism}

Vigilante organizations are heterogeneous; there are many reasons they form. However, economic inequality seems to contribute to the formation of vigilante organizations through two complimentary mechanisms. The overarching idea is that economic inequality leads to security inequality.

Inequality and the relative deprivation of security

Around the world, wealthier citizens often seek out additional security, beyond that which is provided by the government to the typical person. As the security of the wealthy increases, poorer citizens are likely to feel relatively insecure. In economically unequal areas, regarding security, there is an issue of relative deprivation (Gurr, 1970). The notion that local inequality can uniquely heighten tensions, as citizens are more aware of the other group, is consistent with survey data. For example, in situations of high inequality, wealthier citizens are especially likely to believe in meritocracy, while poorer citizens are especially unlikely to believe in it. This difference does not occur in localities that are relatively equal (Newman et al., 2015). In areas with substantial security inequality, the feeling of relative insecurity or deprivation could encourage poorer citizens to form vigilante organizations.

Security inequality can stem from the use of private security, and also issues related to public security. Regarding private security, citizens who can afford to do so use a number of anti-crime measures. Private guards protect many apartment buildings, gated 
communities, and places of work, among other locations. Guatemala, for example, has about 20,000 police officers, but " 120,000 private guards watch over those who can afford to hire them." (United Nations Development Program, 2013). Interestingly, some of the countries with the highest inequality levels are also the countries with the highest saturations of private security firms. ${ }^{8}$

Private security is increasingly used for a variety of reasons. Investments in private security are sometimes related to spikes in crime, but often not. For example, in the United States, private security spending increased substantially in the 1990s, even as crime was decreasing (Dempsey, 2008, p. 15). A more common explanation for increased use of private security in recent decades is the privatization revolution, the trend toward denationalization of state services (Abrahamsen and Williams, 2011). The new status quo is “post-Keynesian policing” (O’Malley and Palmer, 1996), so citizens with the means to do so continually improve their security.

Poorer citizens are less likely to benefit from the use of private security. Analysis of Latin America by the Associated Press (2014) draws this conclusion: "The guards-for-hire offer protection to the wealthy and middle-classes... Poorer residents get by however they can: forming vigilante groups or paying thugs to leave them alone" (emphasis added). A study of Brazil, which mentions vigilante organizations, argues that vigilantes "may be the only type of private security available to the poor" (Caldeira, 2000, p. 206). This is consistent with the idea of grassroots community vigilante organizations. ${ }^{9}$

\footnotetext{
${ }^{8}$ See the appendix.

${ }^{9}$ Some readers might think that poorer citizens do not need private security, since they are less likely to have expensive possessions that would make them targets for thieves. However, vigilantism is a response to many types of crimes, including suspected rape, livestock, and illegal logging.
} 
Increased use of private security by the wealthy could encourage the government to shift public security services toward the relatively insecure citizens, those with lower incomes. ${ }^{10}$ This would mitigate security inequality. However, there is not much evidence of this occurring. Higher-income citizens generally have disproportionate access to public security institutions, as is discussed below, but do not seem to be willing to give this up because of advantages with private security. According to one argument in the human rights literature, "there are incentives for the 'haves' in society to engage in rent-seeking behavior within governmental institutions, to maintain control of their resources, and to exclude access to those resources by the 'have nots'... (Landman and Larizza, 2009)." Business groups in Central America, relying on private security, lobbied against security taxes, and their use of private security was argued to be an important factor in this preference. ${ }^{11}$

Public security, the responsibility of the police and the judiciary, also is likely to be more unequal in situations of economic inequality. Independently of state capacity, the willingness of state actors to provide quality services can vary substantially. Abrahamsen and Williams $(2011,65)$ argue that privatization of public security has not necessarily led to less state ability, but "priorities have shifted," with police forces often used for "private political purposes." Given some degree of informality, and finite public resources, government agents can choose to provide better services - or services at all - to certain citizens. Security services are likely to go to those with disproportionate influence over the

\footnotetext{
${ }^{10} \mathrm{I}$ thank a reviewer for pointing out this possibility.

${ }^{11}$ Regarding this case, the wealthy "don't get security from the state, and therefore are not willing to pay taxes," argues one analyst, who previously was Costa Rica's planning and economic policy minister (Walter, 2011).
} 
system, as well as those able to pay bribes or otherwise subsidize services. ${ }^{12}$ This leads to inequality in justice, and participants in vigilante groups often list lack of access to the criminal justice system as an important motivation (Chouza, 2014).

Evidence of the importance of state agent discretion in explaining vigilantism occurs in a number of contexts. Regarding the formation of citizen militias in Cameroon, "the ill-will of the government on the provision of security" is cited as an important factor (Banseka, 2005). Interview evidence from Bolivia suggests that law enforcement discretion tends to favor wealthier residents - which in turn is offered as a justification for vigilantism. "Many people claimed that only the rich or the middle class get police attention, because they are the only ones who can afford it," summarize the study's authors (Goldstein et al., 2007, p. 53, emphasis added). In situations of greater economic inequality, the disparity in security - private or public - is especially acute. Given the lack of means for poorer citizens to acquire (legal) private security, and relatively little attention from state security services, poorer citizens in this situation seem prone to organize their own security.

\section{Inequality and patron-funded vigilantism}

\footnotetext{
${ }^{12}$ It might be argued that wealthy people, particularly in developing countries, do not necessarily want police protection. They seem to prefer private security. However, there are still reasons why wealthier citizens might "siphon off" public security, contributing to security inequality. First, public security is not only policing, but also prosecution. There is evidence that crimes victimizing wealthy citizens are more likely to be prosecuted (McDonald, 1977, p. 300; Reames, 2007, p. 77). Second, citizens with disproportionate access to public security services, including through bribes, are also protected from the police. In many countries such as Mexico, police demand protection money, and those who do not pay might face consequences.
} 
The second reason that economic inequality can lead to organized vigilantism is because inequality indicates a distribution of labor that mitigates collective action problems for forming self-defense groups. In a locality with relatively equal wealth distribution, it might be challenging to get a group of citizens to take the law into their own hands. Who would lead? Who would provide funding? Which residents would engage in the dirty work of actual violence?

When wealth is concentrated in the hands of the few, a structure is present that can be exploited for organized vigilantism. Relatively wealthy residents could act as patrons, and fund a group of poorer residents as an informal private security force. These are the patron-funded groups described previously. This dynamic has played out in various places throughout the world as business owners fund lower-income residents, perhaps their own employees, to take up arms as vigilantes.

This is precisely how some autodefensa groups started in Colombia in the 1980s. After a wave of kidnappings and extortion, wealthy citizens including drug traffickers and cattle ranchers created groups to take the law into their own hands. (e.g., Human Rights Watch, 1996). ${ }^{13}$ In Nigeria, traders' associations founded and funded the famous vigilante group the Bakassi Boys to deter armed robberies (Ibrahim, 2005). In Mexico, business owners in Ciudad Juárez funded some vigilante groups (Petrich, 2011, Washington Valdez 2011). In rural areas of Mexico, ranchers funded and led vigilante groups (Milenio, 2014). This is discussed more below. Overall, the combination of relatively wealthy patrons and a corps of workers willing to protect them seems to be an environment conducive to the

\footnotetext{
${ }^{13}$ Some of these groups eventually became, or originally were, pro-state paramilitaries, challenging the power of leftist groups as "social control" vigilantes (Rosenbaum and Sederberg, 1970). However, at least initially, some of the groups were more traditional vigilante groups, primarily focused on confronting kidnappers and extortionists.
} 
formation of vigilante groups. This combination is more likely to exist in areas with greater inequality.

This mechanism is about the opportunity structure that inequality can provide.

Prominent studies have described inequality as only a grievance, and therefore not a condition that on its own makes organizing violence feasible (Collier, Hoeffler, \& Rohner, 2009). Organizing violence, getting individuals to engage in illegal and dangerous behavior, represents a substantial collective action problem (Lichbach, 1995). However, since this mechanism is specifically about feasibility or opportunity, it suggests inequality can contribute to organized violence in ways beyond the traditional grievance pathway.

Overall, there are a variety of types of vigilante organizations, and inequality seems to contribute to more grassroots community vigilantism (the first mechanism), as well as patron-funded vigilantism (the second mechanism). As a result of these two causal pathways, citizens in situations of economic inequality should be more likely to take up arms against criminals. This is the basic hypothesis of this study: local economic inequality is positively associated with the presence of vigilante organizations.

\section{Vigilantism in Mexico}

Vigilantism has a long history in Mexico (Kitchens, 1967). There is also a history of legal community defense, particularly in indigenous communities, which sometimes practice self-governance through the usos y costumbres framework. In the 1990s, community police organizations formed in Guerrero, but these groups are different from the vigilantes of 2013, and vigilantes generally, due to their legality (Salgado, 2013). Other legal security collectives include neighborhood watch associations (Vilalta, 2013), which usually report suspected criminals to the police instead of using force against them. 
Mexico, like other countries, has also seen lynchings and similar vigilantism. In Mexico City there were five acts of violent street justice reported in 2013, and several more in 2014 (Fuentes, 2014).

Throughout the country, groups of citizens have taken the law into their own hands to bring "justice" to perceived criminals. One expert argues that such acts have increased since the year 2000 (Grillo, 2009). Vigilantism in Mexico during these years has often been unorganized - mob violence, or carried out by friends and families of a victim. However, with the start of Mexico's militarized "war" against drugs in 2006, a few vigilante organizations began to appear in various corners of the country. As most of the violence in those years was in the north of the country, that is where some of the first vigilante groups emerged. Violence spread throughout the country in the years that followed, and to some degree vigilantism spread with it.

In 2008 in the border city of Ciudad Juárez, a group called the Citizen Front Against Corruption and Violence announced its presence, and was possibly responsible for the deaths of drug dealers and corrupt police officers (Cano, 2009). In 2011 in the town of Cherán, Michoacán, residents attacked illegal loggers connected to drug-traffickers - and forced out the local police - in a bold uprising that foreshadowed events of 2013 (Martínez Elorriaga, 2011). These acts, however, were isolated. Overall, since the 2006 start of Mexico's militarized confrontation with criminal groups, vigilantism rarely occurred against these groups. ${ }^{14}$ One expert suggested, "it is ironic that vigilante acts do not appear to be increasing amid the atmosphere of violence afflicting Mexico" (Grayson, 2011).

\footnotetext{
${ }^{14}$ There were other citizen responses to violence in these years, such as social movements and protests (e.g., Gallagher 2012), but usually the intended audience was the national government.
} 
This changed in 2013. In January, many communities in Mexico apparently reached a tipping point, and vigilante organizations sprung up almost overnight. One important event was in Ayutla, Guerrero, in southern Mexico, where a criminal gang kidnapped a community delegate. Residents armed with guns and machetes freed the delegate (International Crisis Group, 2013). This inspired people in nearby municipalities to take up arms and hold demonstrations, and these actions were broadcast widely through the news media (e.g., Casey, 2013). Other groups formed in the neighboring state of Michoacán, and across the country. In February, for example, a vigilante group had formed in Mexico State, just outside Mexico City (Montaño, 2013). By fall of 2013, the National Human Rights Commission acknowledged that vigilante organizations had formed in at least 10 states (Alcántara, 2013).

There seems to have been important diffusion effects in the emergence of vigilante organizations in Mexico in 2013. The news media apparently played a critical role, as citizens learned about vigilante actions elsewhere in the country, and were inspired to start their own group. The role of the news media in social movement diffusion has been observed in other contexts (Kern, 2011). Occasionally groups in Michoacán spread when vigilantes from one town would help "liberate" a neighboring town, forcing out organized crime so that a local vigilante organization could control the town (La Jornada, 2013). A more common way vigilantism traveled spatially was through learning and interpersonal communication. For example, the citizens of La Ruana, Michoacán formed the state's first vigilante organization on Feb. 24, 2013, and soon after groups formed in the neighboring 
towns, Buenavista and Tepalcatepec (Mayorga, 2014). ${ }^{15}$ This was apparently neighbor emulation diffusion (Brinks \& Coppedge, 2006).

Actions by vigilante organizations varied considerably. In many cases they protested at government buildings (Cabrera, 2013), or patrolled their neighborhood in a show of force (Martínez Elorriaga \& Ocampo Arista, 2013). They set up roadblocks, to try to catch members of criminal organizations (Gil Olmos, 2013). In some instances vigilante groups detained suspected criminals, conducting their own trials (Covarrubias \& Cervantes, 2013). Sometimes they killed suspected criminals (Covarrubias, 2013). In the state of Michoacán, they at times engaged in firefights with organized crime groups over control of particular towns (Carrión Enviada, 2014). In a few cases, vigilante organizations stormed local city halls and "arrested" the local police forces they considered corrupt (García Davish, 2014).

The situation apparently peaked in January 2014. Vigilantes had been losing public support, as reports appeared that some vigilantes were extorting their fellow citizens (Becerra Acosta, 2014). Some of the groups had evidently been corrupted, and were being armed by one criminal group to fight another (Mercado, 2014). As violence increased in Michoacán in particular, the Mexican government deployed the military, taking over the security of the state. At the end of the month, the government legalized some of the apparently un-corrupted vigilante organizations. These groups registered their weapons, among other steps, and were christened the Rural Defense Force. By early February, the force had 500 members (Muédano, 2014). While some vigilante organizations continue to exist in various parts of the country, the uprising that started in early 2013 had mostly ended a year later.

\footnotetext{
${ }^{15}$ For in-depth analysis of vigilantes in Tepalcatepec, Michoacán, see Guerra (2016).
} 
Inequality and organized vigilantism in the Mexican case

There have been diverse explanations offered for why Mexican vigilante organizations formed in 2013. Many press accounts simply say the citizens were "fed up with crime" (Calderón, 2014). Other accounts emphasize another traditional explanation for vigilantism - the inability of the state to stop crime, and more broadly protect the rights of all citizens (Zurita Eraña, 2014). For example, one Mexican analyst argues that the cause of vigilantism is nothing new in the country: it is related to the "absence or inefficiency of a state function: public security provision" (El Universal, 2013). Perceptions of injustice were widespread, and vigilantes were seen as one response to this problem. This explanation, however, does not indicate why vigilantism did not occur in the most crimeinfested areas, or everywhere - given widespread crime and famously under-resourced municipal police.

Inequality helps explain why vigilante organizations emerged in some areas instead of others. Regarding the mechanism about economic inequality leading to security inequality, and poorer citizens forming groups for their own defense, we see evidence of this in Mexico. The idea of security inequality might explain why poor Mexicans are more likely than wealthier Mexicans to express support for vigilante justice (Zizumbo, 2010). Poorer citizens are disadvantaged in terms of private and public security, consistent with the argument.

Wealthier citizens in Mexico are protected by a great deal of private security. As in other countries, the use of private security in Mexico surged in the 1990s, but gained additional steam when the "drug war" began. Estimates vary, but for example a $40 \%$ increase in private security spending was reported in 2011 relative to the previous year 
(SDP Noticias, 2011). Beyond elite services such as bodyguards, private security is employed in workplaces, apartment buildings, and private neighborhoods. Mexico has one of the highest concentrations of gated communities in the world (Provost, 2014), where the inequality between those inside the walls and those outside is stark (Enríquez Acosta, 2007). Wealthy Mexicans have taken a number of additional measures in the face of rising crime. "The upper middle class and the rich are turning to bulletproofing their cars," reports one news story, also describing a trend of installing GPS trackers in cars, and the sale of expensive bulletproof clothing (Iliff, 2008). Wealthy citizens apparently had many options able to be relatively safe from the violence in the country.

Beyond private security leaving poorer citizens to their own defenses, intentional choices of public security officials also seem to play a role in the Mexican case. Consistent with this article's argument, anecdotal evidence suggests that the government is seen as intentionally abandoning citizens, at least poorer citizens. Dr. José Manuel Mireles, the well-known leader of a vigilante group in Tepalcatepec, Michoacán, said his group had only two demands: "public security and access to the administration of justice" (Chouza, 2014). The concern about "access" is consistent with the notion of some citizens feeling left out of the process. Another group leader from Michoacán makes a similar argument. "This is a poor people's movement... We are abandoned, for the state it is as if we do not exist" (Prados, 2013, emphasis added).

Government officials have also acknowledged that the state has not been providing the security that it should. In 2013, the president of Mexico's National Human Rights Commission said that the appearance of vigilantes was a warning sign for authorities "to fulfill their obligation to provide public security" (Gandaria, 2013). He further said that in various parts of the country, the situation was ripe for self-defense groups because of 
"abandonment and impunity" (ibid.). Some of the issues of injustice in Mexico, such as the only 2 percent sentencing rate for homicides in recent years (Pachico, 2013), are at least in part due to lack of capacity. However, corruption plays a substantial role as well. Mexican security expert Raúl Benitez, for example, argues that a war against crime will not succeed without a "war against corruption" (Prados, 2013).

It was suggested in the argument that wealthier citizens have privileged access to public services, including security, through various means. Regarding corruption, and bribery in particular, there is substantial evidence of this behavior in Mexico (Transparency International, 2013). Given the extensive nature of corruption in Mexico, areas with more economic inequality should see public security services going to citizens with more money. This is consistent with vigilante groups demanding an end to corruption (Covarrubias, 2013b), and various analyses that suggest the groups emerged at least partly because of corruption (Egui Brito, 2014). This disparity in public security provision, along with unequal access to private security, should increase the likelihood of citizens turning to organized vigilantism.

Regarding the mechanism where unequal income distribution makes it possible for relatively wealthy citizens to organize vigilante groups, this has occurred in a number of instances. In the state of Michoacán, local ranchers supported or even led some vigilante groups. A prominent example is lemon grower and rancher Hipólito Mora, who founded and led a group in that state (Milenio, 2014). He reportedly owns about 37 acres of lemon orchards (Cano, 2014), and other vigilante leaders in Michoacán also own substantial tracts of land (Milenio, 2014). In Ciudad Juárez, local business owners funded several groups, as discussed. Consistent with the argument that inequality creates an environment where business leaders can fund hitmen in vigilante groups, this is exactly what happened in 
Ciudad Juárez. In the case of the Citizen Command for Juárez, the group was literally former hitmen - former Zetas contracted by four local business owners (Ramsey, 2011). ${ }^{16}$ Other business owners created the United Junkyard Owners (Petrich, 2011). In sum, we do see examples in Mexico of patron-funded vigilante groups.

Anecdotally, the Mexican case suggests some support for the theorized connections between inequality and organized vigilantism. There is evidence for the first mechanism, where inequality has led to security inequality - encouraging poorer citizens to take the law into their own hands. There is also support for the second mechanism, where wealthy patrons fund or lead vigilante groups made up of poorer citizens. This occurred in a variety of places in the country. The next section seeks to more systematically analyze the Mexican case, taking alternate explanations into consideration.

\section{Data and analysis}

Analyses are conducted on a cross-section of all Mexican municipalities for which there are sufficient data, with dependent variable data from 2013 and independent variable data from 2012, or the most recent pre-2013 year possible if no data were available in 2012. The primary models include around 2,440 observations, almost all of Mexico's municipalities. Other models have fewer observations because of missing data on variables. Logistic regression is used due to the nature of the dependent variable, with robust standard errors (Zorn, 2006).

\footnotetext{
${ }^{16}$ Interestingly, this group also reportedly had connections with the Mexican military (Petrich, 2011; Ramsey, 2011). This seems comparable to dynamics of the Colombian autodefensas. The Juárez group, however, was apparently relatively isolated and shortlived.
} 
The dependent variable is vigilante organization, a dichotomous variable coded "1" for those municipalities in which a vigilante organization operated in 2013. To code this variable, Mexican media sources were searched, such as the newspapers El Universal and Milenio, as well as the website Animal Politico. The variable is coded according the definition discussed earlier. There are 75 municipalities coded "1" for the variable. Many of the groups are located in the south of Mexico, with disproportionate numbers in the states of Guerrero (21 municipalities) and Michoacán (18). However, groups are distributed throughout the country, in 13 of the 32 federal entities.

The year 2013 is chosen because that is when a wave a vigilante organizations emerged, so they seem relatively comparable - as opposed to vigilante organizations founded at various times throughout history. Additionally, since most of the groups were founded within one year, causal factors from the previous year can be analyzed to attempt to determine why groups formed where and when they did. The collection of the variable was also limited to 2013 because the national context changed substantially in early 2014 , when the government legalized some of the groups. Groups that emerged after this legalization might have been motivated by different factors than those pre-legalization. Independent variable information is gathered from 2012 or as close to it as possible, but not from 2013, to mitigate potential reverse causality issues. The variable inequality is used to measure economic inequality in the municipality. It is the Gini coefficient, a standard measure of inequality, and comes from the National Council of Evaluation of Social Development Policy. It theoretically ranges from 0 to 1 , where 0 indicates equality and 1 indicates perfect inequality, and in this sample it ranges from .286 to .591 . A coefficient of .286 is approximately the inequality of Denmark or the Netherlands, while a .591 indicates inequality at a level between Honduras and South Africa. A map of the 
subnational distribution of economic inequality is shown in the appendix. Gini is not perfect, but it probably the most widely used measure of economic inequality, and the most available subnationally for Mexico. Education inequality is also examined in the empirical tests to determine if other types of inequality are associated with vigilantism, or if economic inequality in particular is uniquely important.

To measure prominent alternative explanations, models include various measures of crime rates, as well as government capacity. The primary measure of crime is the 2012 homicide rate. This variable comes from INEGI, and is deaths ruled homicides, per 100,000 inhabitants. Homicides are used because it is possible that only serious crime such as this might inspire citizens to take up arms. More practically, homicide data are much more reliable than Mexican data on other crimes. A squared term of the homicide rate is also used, to see if a non-linear relationship exists. Another model includes the yearly change in the homicide rate from 2011-2012. Another includes the general crime rate. This variable uses 2010 crime data, and comes from INEGI. The appendix also shows models with rates of drug-related homicides, kidnapping, extortion, and drug-dealing, as well squared terms of these variables.

The primary measure of state capacity is GDP per capita ("producción bruta total" divided by population), in thousands of pesos. This is admittedly not an ideal measure, but it is used elsewhere as a proxy for government capacity (Fearon \& Laitin, 2003). It is used here as the primary measure because other measures have substantial missing data. The source is INEGI, via the EVES database (Bravo Regidor et al., 2014). The data are from 2008 , but do not change substantially over time. The more substantial variation is across municipalities. A model also includes the squared version of GDP per capita, to test a possible non-linear relationship. 
One alternate measure of state capacity is libraries per capita. This measure is admittedly not a measure of security or justice capacity, but is a proxy for overall government capacity. It has the advantage of being relatively exogenous to security issues. Data come from INEGI in 2010. Another state capacity measure is municipal government income as a percentage of municipal government spending. This measure is sometimes referred to as "fiscal autonomy." It comes from the National Institute for Federalism and Municipal Development, and is from 2011. Only 1,322 municipalities have data for this variable, so results should be taken with caution. Squared terms for these variables are shown in the appendix.

To capture another prominent argument in the literature, the cultural and particularly indigenous explanation, models include indigenous language, which is the percentage of residents of the municipality age 5 years or older that speak an indigenous language. This variable comes from the INEGI, and data come from 2010. Another measure was tested, percent of land that is communal under the ejido framework, and results were similar.

Beyond the independent variables testing alternative explanations, models include a number of control variables. All models include a natural logarithm of municipal population. They also include a geographic or diffusion measure, vigilantes in neighbor. This variable is coded 1 if there is a vigilante group in one of the municipalities bordering the municipality being analyzed. Models also include urban population, a measure of the percentage of the population living in urban areas, because organized vigilantism is often a rural phenomenon. Data come from INEGI in 2010. Finally, models include a measure of the percent of households reporting remittances from the United States. Anecdotal evidence suggests at least some of the groups were supported by funds from Mexicans living in the 
United States. This variable comes from the National Population Council, via the EVES database.

Results

Results are in Table 1. The first model is the primary model. The main independent variable, inequality, is statistically significant and positively signed, suggesting that municipalities with more inequality are more likely to have a vigilante organization operating in them. This result is robust across all models. The use of marginal effects suggest a standard deviation change in income inequality is associated with a $24 \%$ increase in the probability of a vigilante organization being present in the municipality, other factors held constant. This is a more substantial effect than any other variable in the models. As a comparison, if a municipality goes from "0" to "1" on the variable vigilantes in neighbor, the estimated change in the probability in the municipality having a vigilante organization is only a $7 \%$ increase.

[Table 1 about here.]

In Model 1, independent variables representing alternative causal explanations are statistically insignificant. Neither the 2012 homicide rate nor GDPPC - the measure of state capacity - are statistically associated with the presence of a vigilante group. ${ }^{17}$ This is somewhat surprising, and is discussed more below. Regarding other explanations, the variable measuring the percent of the population that speaks an indigenous language is statistically insignificant. This suggests that "cultural" arguments for vigilantism being

${ }^{17}$ If the homicide rate and GDPPC are interacted, and the results graphed, there is never a statistically significant relationship with organized vigilantism. 
rooted in indigenous cultures do not find support in these tests. If an alternative measure is used, the percent of land that is communal land under the ejido framework, the variable remains statistically insignificant and other results are unaffected.

Model 2 includes squared terms of both the homicide rate and per capita income, to see if there are nonlinear relationships between these variables and vigilantism.

Interestingly, both the homicide measure and its squared term are statistically significant, and jointly suggest that homicide is associated with organized vigilantism at moderate levels of the homicide rate. In other words, there is an inverted-U relationship between homicide and vigilantism. This could be because some level of serious crime is necessary to inspire vigilantism, but if violent crime levels become too high, it is too dangerous for vigilantes to operate. This provides some support for the notion that violent crime is related to vigilantism. The insignificance of the GDPPC measure and its square term in Model 2 suggests there is no support for the idea of an inverted-U relationship between state capacity and vigilantism in this model. In the appendix, a few of the alternate measures of crime and state capacity show non-linear relationships with vigilantism, but there is not consistent support for this type of relationship. The appendix results are discussed more below.

Models 3-6 include alternate measures of crime (change in the homicide rate, and general crime rate) and state capacity (libraries per capita and fiscal autonomy). None of the alternate measures is statistically associated with organized vigilantism.

Regarding other variables, population is statistically significant and positive, suggesting municipalities with larger populations are more likely to see a vigilante organization emerge. Vigilantes in neighbor is consistently statistically significant and 
positive, suggesting municipalities in such a condition are more likely to have vigilante organizations. This is consistent with qualitative evidence of diffusion.

Urban population is negatively signed, as expected, never statistically significant. Migrant remittances is positively signed as expected, but is only marginally statistically significant $(\mathrm{p}<.10)$ in one model. Anecdotal evidence suggests migrants in the United States sent funding to some vigilante groups, but this might not have been a widespread phenomenon.

\section{Additional models in the appendix}

The appendix shows additional tests. Models show squared terms of crime and state capacity measures used in the main results table. None are statistically significant, except fiscal autonomy and its squared term. However, the results are counterintuitive - they suggest vigilantism is less likely at low levels of state capacity, but the effect diminishes as capacity increases. The fiscal autonomy measure is missing data on almost half the observations, so this result should be taken with considerable caution.

Regarding alternate measures of crime, the appendix tests five measures of crime, and two (a drug-related homicide variable and extortion) suggest a non-linear relationship between the type of crime and vigilantism. ${ }^{18}$ This adds some evidence to the notion, shown with homicide rates in Model 2, that crime affects vigilantism, but that this effect diminishes as crime increases beyond a certain point.

Two appendix models explore whether the conviction rate in a municipality is associated with vigilantism. Low conviction rates could be an indicator of injustice, and impunity in particular, which has been cited as a grievance among vigilantes. However,

\footnotetext{
${ }^{18}$ The extortion measure is only marginally statistically significant.
} 
neither measure is statistically associated with vigilantism. Another model includes measures of which drug-trafficking organization had been operating in the municipality, because of the possibility that vigilantism is a response to certain types of groups. The only variable statistically associated with organized vigilantism is the measure of the Juarez Cartel. However, it is marginally significant, and the substantive significance is low. It does not seem that the actions of one particular group contribute much to explaining organized vigilantism in general.

A measure of a different type of inequality, education inequality, is also tested in the appendix. Education inequality is measured by, for each municipality, the ratio of the number of residents with a post-graduate degree to the number of residents who cannot read or write. The argument of this article was about economic inequality, so education inequality should not necessarily be related to vigilantism. Indeed, the coefficient on education inequality is statistically insignificant. This suggests that it is not inequality generally, or other types of inequality, that are associated with vigilantism. As other research has shown, different types of inequality have divergent consequences. In this manuscript was theorized that economic inequality is related to security inequality, and the lack of relationship found for education inequality is consistent with this.

Finally, an appendix model excludes municipalities in the state of Guerrero. This is because Guerrero has a considerable history of legal community policing, and this could be affecting results. However, even with Guerrero excluded, results from Model 1 do not substantially change. Overall, the results for economic inequality are highly robust to many changes in model specification.

\section{Discussion}


The lack of statistically significant relationships between organized vigilantism and many crime measures or state capacity measures is somewhat surprising. On the one hand, other studies have shown that vigilantism often does not appear in the areas with the highest crime or weakest government. On the other hand, it is likely that vigilantism would not have emerged in 2013 if crime levels were low and security institutions capable. So why is there a disparity between this conventional wisdom and the empirical results?

Regarding crime, the finding of an inverted-U relationship between some crime measures and vigilantism helps us to understand the role of crime in community selfdefense. The lack of results for other crime variables should not be interpreted as an indication that crime plays no role in the emergence of vigilantism. The widespread nature of criminal violence in Mexico since 2006 (like the pervasive weak security institutions) might make specific municipal levels less relevant. It can also be, as has been argued, that vigilantism has diverse causes and types. In some towns, vigilantism was a response to murder, but in others it was a response to kidnapping. As a result, measures of either type of crime are unlikely to show a general effect.

Regarding state capacity, weak security institutions are endemic in Mexico, so perhaps subnational variation in state capacity is not meaningful for explaining vigilantism. A certain level of state weakness seems necessary for vigilantism, and it could be that most Mexican municipalities meet the criterion. This is likely the case for many developing countries. Another possibility is that there is within-municipality variation that is difficult to measure - vigilantism might have emerged in a municipality with "average" state capacity, but perhaps in part of the municipality with the least attention from the government. Future research could look into smaller units, such as grid squares, to explore within-municipality variation. 
One limitation of the empirical tests is the lack of time dynamics in the models. Regarding diffusion, the best way to demonstrate spatial diffusion is using time-series data. In order to show spatial effects, as opposed to some common underlying phenomenon, the spatial variable (Vigilantes in neighbor) should ideally be temporally lagged (Franzese and Hays, 2008, p. 758). The primary focus of this article is inequality, not diffusion, but a more fine-grained look at the diffusion of vigilantism would make for important future research.

Due to the lack of time-varying data, the data is not able to answer other questions about timing, such as why vigilantism emerged in 2013 more than other years. As discussed in the qualitative analysis, there seem to have been a tipping point and diffusion effects, at least partly related to the geography of crime in Mexico. When crime initially increased in northern Mexico, where inequality is relatively low, there was not much vigilantism. However, as crime spread several years later to southern Mexico, which is more unequal, vigilantism appeared substantially. Vigilantism occurred in other parts of the country as well, but generally in area with high levels of inequality. Beyond the possibility of changes in crime (which did not find much support in empirical tests), another potential factor is the change in Mexico's president in 2012. Perhaps public doubts about changes in federal security policy contributed to the likelihood of vigilantism at that time.

Are the findings from this study applicable to other countries? Mexico has a fairly weak institutions, and has been experiencing relatively high levels of crime. These could be scope conditions for other areas to which generalizations could be made. In other countries with these conditions - many developing countries - we might also see inequality leading to organized vigilantism. Indeed, examples mentioned previously showed the theorized causal mechanisms at work in Brazil, Colombia, Honduras, and South Africa. Not 
coincidentally, I would argue, these countries also score high in terms of economic inequality. There are also local factors that contribute to and condition causal factors such as inequality. In the Mexico case, the war on drugs was obviously important. However, this can be seen as an example of a more general phenomenon, a crime wave. Overall, Mexico, as a developing country experiencing higher crime levels than it had been, is comparable to many other countries.

A related question is why Mexico had so many vigilante organizations, while at least some of the other countries mentioned above apparently have had fewer. A number of local-context issues in Mexico could explain this. The tradition of community policing in some parts of the country is likely to have played a role, although vigilantes also emerged in many areas without such traditions. The widespread nature of organized vigilantism could also have been related to qualitative differences in criminal violence, with violence in Mexico sometimes involving terrorist tactics. This could have been especially shocking to citizens. So Mexico is an extreme case in some senses, but we could still expect the theoretical mechanisms to function in other countries, perhaps with a less severe outcome in terms of the number of groups.

\section{Conclusion}

Throughout the world, vigilantism occurs when citizens decide to administer justice themselves instead of depending on police and courts. Vigilantism is often an indicator of serious governance problems, and it can have deleterious consequences. Vigilante organizations, as opposed to individuals or random mobs, suggest deep-rooted challenges to traditional authority. In spite of the importance of this phenomenon, there is little research on why vigilante organizations form. 
This article presented an argument for why local economic inequality is likely to be related to organized vigilantism. This occurs through two mechanisms, leading to the two ideal-types of vigilante groups, grassroots community organizations and patron-funded groups, respectively. The argument finds some support in anecdotal evidence from the recent uprising of vigilante groups in Mexico. Examples of the causal mechanisms are also apparent in some other countries as well. Regarding more systematic empirical evidence, quantitative analyses of Mexico's more than 2,000 municipalities showed that income inequality is robustly associated with municipalities with a vigilante organization.

The analyses did not find much support for competing explanations, such as high crime, low state capacity, or indigenous population. The one exception is that there seems to be an inverted-U relationship between some crimes and organized vigilantism. Vigilantism emerged in areas with moderate levels of crime, but this effect disappears at higher levels of crime.

It should be acknowledged that inequality on its own is probably insufficient to explain vigilantism. Mexico's self-defense groups would not have emerged if crime were not an issue, or if the government were fully capable and willing to protect citizens. Common quantitative measures did not consistently show associations between crime and vigilantism, or state capacity and vigilantism. However, in Mexico - like in many developing countries - crime is widespread and local authorities are under-equipped. One way to interpret the findings of this study would be that assuming some degree of crime and state weakness, economic inequality increases the likelihood of vigilantism. Therefore it is likely that inequality should play a role in vigilantism in countries beyond Mexico.

A number of questions remain. First, as discussed, the present study did not seek to explain the timing of vigilantism, why vigilante organizations appeared across Mexico in 
2013 as opposed to other years. Future research should investigate this temporal question, but time-series data would be needed. Additionally, while there seems to be a relationship between inequality and vigilantism in this particular case, does the same relationship occur in other countries subnationally, or cross-nationally? A glance at income inequality data suggests that some of the countries with the highest Gini coefficients are also known for vigilantism, but this is worth additional investigation. A related question is whether inequality explains individual or lynch-mob vigilantism. This is possible through the causal mechanism of security inequality and relative deprivation, but should be studied further. The second mechanism is unlikely to explain individual vigilantism, as it deals with organizing a group.

Finally, it was noted that inequality has been dismissed by many scholars of civil conflict as only a grievance factor that is unable to explain conflict on its own. If inequality helps organize vigilante groups, under what conditions might inequality contribute to other types of violence, including militia violence? Subnational or even group-level studies might be ideal to address this type of question.

Scholars have long studied inequality. Vigilantism, on the other hand, has been under-analyzed in political science, although that seems to be changing in recent years (e.g., Bateson, 2013; Bateson and Smith, 2015; Rojo Mendoza, 2015). The apparent connection between these two topics, at least in the Mexican case, will hopefully encourage more investigation into factors that facilitate vigilantism, and perhaps also spur more research on inequality. These phenomena are not only theoretical interesting, but have serious consequences that demand their attention as well. 


\section{Table}

Table 1. Logistic regression of vigilante presence in Mexican municipalities, 2013.

\begin{tabular}{|c|c|c|c|c|c|c|}
\hline & $\begin{array}{l}\text { Model } 1 \\
\text { Main } \\
\text { model }\end{array}$ & $\begin{array}{c}\text { Model } 2 \\
\text { Squared } \\
\text { terms }\end{array}$ & $\begin{array}{l}\text { Model } 3 \\
\text { Alternate } \\
\text { crime } \\
\text { measure }\end{array}$ & $\begin{array}{l}\text { Model } 4 \\
\text { Alternate } \\
\text { crime } \\
\text { measure }\end{array}$ & $\begin{array}{c}\text { Model } 5 \\
\text { Alternate } \\
\text { state } \\
\text { capacity } \\
\text { measure }\end{array}$ & $\begin{array}{c}\text { Model } 6 \\
\text { Alternate } \\
\text { state } \\
\text { capacity } \\
\text { measure }\end{array}$ \\
\hline Inequality & $\begin{array}{c}10.78 * * * \\
(3.727)\end{array}$ & $\begin{array}{c}9.917 * * * \\
(3.835)\end{array}$ & $\begin{array}{l}11.34 * * * \\
(-3.777)\end{array}$ & $\begin{array}{l}10.58 * * * \\
(-3.759)\end{array}$ & $\begin{array}{l}11.15 * * * \\
(-3.819)\end{array}$ & $\begin{array}{l}9.916^{* *} \\
(-4.346)\end{array}$ \\
\hline Homicide rate & $\begin{array}{l}.000 \\
(.004)\end{array}$ & $\begin{array}{c}.031^{* * *} \\
(.012)\end{array}$ & & & $\begin{array}{l}-.000 \\
(-.004)\end{array}$ & $\begin{array}{l}.002 \\
(-.004)\end{array}$ \\
\hline $\begin{array}{l}\text { Homicide rate } \\
\text { squared }\end{array}$ & & $\begin{array}{c}-.000^{* * * *} \\
(.000)\end{array}$ & & & & \\
\hline $\begin{array}{l}\text { Change in } \\
\text { homicide rate }\end{array}$ & & & $\begin{array}{c}-.006 \\
(-.004)\end{array}$ & & & \\
\hline Crime rate & & & & $\begin{array}{l}-.000 \\
(-.000)\end{array}$ & & \\
\hline GDPPC & $\begin{array}{l}-.0237 \\
(.020)\end{array}$ & $\begin{array}{l}.037 \\
(.128)\end{array}$ & $\begin{array}{l}-.0274 \\
(-.026)\end{array}$ & $\begin{array}{l}-.0206 \\
(-.016)\end{array}$ & & \\
\hline $\begin{array}{l}\text { GDPPC } \\
\text { squared }\end{array}$ & & $\begin{array}{l}-.001 \\
(.003)\end{array}$ & & & & \\
\hline Libraries per capita & & & & & $\begin{array}{l}-.006 \\
(-.019)\end{array}$ & \\
\hline Fiscal autonomy & & & & & & $\begin{array}{c}-.045 \\
(-.030)\end{array}$ \\
\hline $\begin{array}{l}\text { \% population } \\
\text { indigenous }\end{array}$ & $\begin{array}{l}-.027 \\
(.618)\end{array}$ & $\begin{array}{l}.174 \\
(.619)\end{array}$ & $\begin{array}{l}-.076 \\
(-.614)\end{array}$ & $\begin{array}{l}-.103 \\
(-.621)\end{array}$ & $\begin{array}{l}-.088 \\
(-.614)\end{array}$ & $\begin{array}{l}-.204 \\
(-.649)\end{array}$ \\
\hline $\begin{array}{l}\text { Population } \\
\text { (log) }\end{array}$ & $\begin{array}{c}.536^{* * *} \\
(.136)\end{array}$ & $\begin{array}{c}.514^{* * *} \\
(.136)\end{array}$ & $\begin{array}{l}.529 * * * \\
(-.135)\end{array}$ & $\begin{array}{c}.585^{* * *} \\
(-.165)\end{array}$ & $\begin{array}{l}.509 * * * \\
(-.152)\end{array}$ & $\begin{array}{c}.535^{* * *} \\
(-.17)\end{array}$ \\
\hline $\begin{array}{l}\text { Vigilantes in } \\
\text { neighbor }\end{array}$ & $\begin{array}{c}3.294 * * * \\
(.305)\end{array}$ & $\begin{array}{c}3.272 * * * \\
(.315)\end{array}$ & $\begin{array}{c}3.292 * * * \\
(-.304)\end{array}$ & $\begin{array}{c}3.241 * * * \\
(-.316)\end{array}$ & $\begin{array}{c}3.203 * * * \\
(-.306)\end{array}$ & $\begin{array}{c}3.065^{* * *} \\
(-.374)\end{array}$ \\
\hline Urban population & $\begin{array}{l}-1.984 \\
(1.880)\end{array}$ & $\begin{array}{l}-2.151 \\
(1.967)\end{array}$ & $\begin{array}{l}-1.866 \\
(-1.813)\end{array}$ & $\begin{array}{c}-1.76 \\
(-1.779)\end{array}$ & $\begin{array}{l}-2.186 \\
(-1.928)\end{array}$ & $\begin{array}{l}-1.832 \\
(-2.126)\end{array}$ \\
\hline Migrant remittances & $\begin{array}{l}.026 \\
(.018)\end{array}$ & $\begin{array}{l}.023 \\
(.020)\end{array}$ & $\begin{array}{c}.026 \\
(-.018)\end{array}$ & $\begin{array}{c}.024 \\
(-.018)\end{array}$ & $\begin{array}{l}.033^{*} \\
(-.018)\end{array}$ & $\begin{array}{c}.014 \\
(-.022)\end{array}$ \\
\hline Constant & $\begin{array}{c}-14.74 * * * \\
(1.889) \\
\end{array}$ & $\begin{array}{c}-14.59 * * * \\
(1.928)\end{array}$ & $\begin{array}{c}-14.90 * * * \\
(-1.935) \\
\end{array}$ & $\begin{array}{c}-14.98 * * * \\
(-1.924) \\
\end{array}$ & $\begin{array}{c}-14.49 * * * \\
(-2.289) \\
\end{array}$ & $\begin{array}{c}-13.71 * * * \\
(-2.261) \\
\end{array}$ \\
\hline $\mathrm{N}$ & 2440 & 2440 & 2,440 & 2,402 & 2,316 & 1,322 \\
\hline
\end{tabular}

Robust standard errors in parentheses $* \mathrm{p}<0.05,{ }^{* *} \mathrm{p}<0.01,{ }^{* * *} \mathrm{p}<0.001$ 


\section{Works cited}

Abrahams, Ray. (1987). Sungusungu: Village vigilante groups in Tanzania. African Affairs no. 86 (343):179-196.

Abrahamsen, Rita, and Michael C. Williams. (2011). Security beyond the state: Private security in international politics. New York: Cambridge University Press.

Alcántara, Liliana. (2013). Alertan de expansión de grupos armados: Autodefensas reflejan falta de gobernabilidad. El Universal, Nov. 20, 2013.

Ansell, Ben, and David Samuels. (2010). Inequality and democratization: A contractarian approach. Comparative Political Studies 43 (12): 1543-1574.

Arellano, Lisa. (2012). Vigilantes and lynch mobs: Narratives of community and nation. Temple University Press.

Associated Press. (2014). Private firms filling Latin America's security gap. The New York Times. Nov. 27, 2014.

Baker, Bruce. (2004). Protection from crime: What is on offer for Africans? Journal of Contemporary African Studies no. 22 (2):165-188.

Banseka, Cage. (2005). The 'anti-gang' civil militias in Cameroon and the threat to national and human security." In Civil Militia: Africa's Intractable Security Menace?, edited by David J. Francis. Burlington, VT: Ashgate.

Bateson, Regina Anne. (2012). Crime victimization and political participation. American Political Science Review 106 (3): 570-587.

Bateson, Regina Anne. (2013). Order and violence in postwar Guatemala. Dissertation, Yale University.

Bateson, Regina Anne, and Nicholas Rush Smith. (2015). "Vigilantism: A research agenda for political science." Manuscript.

Becerra Acosta, Juan Pablo. (2014). Michoacán: también las 'autodefensas’ piden diezmo. Milenio. Feb. 24, 2014.

Boix, Carles. (2003). Democracy and redistribution. Cambridge: Cambridge University Press.

Bravo Regidor, Carlos, Marc Grau Vidiella, and Gerardo Maldonado Hernández. (2014). Elecciones, violencia y estructura social (EVES). Base de datos integral de municipios mexicanos. Mexico City: Centro de Investigación y Docencia Económicas.

Brinks, Daniel, and Michael Coppedge. (2006). Diffusion is no illusion: Neighbor emulation in the third wave of democratization. Comparative Political Studies 39 (4): 463-489.

Burrows, William E. (1976). Vigilante! New York: Harcourt Brace Jovanovich.

Cabrera, Carlos. (2013). Autodefensa en Guerrero protesta frenta a Congreso. El Universal. July 1, 2013.

Caldeira, Teresa P.R. (2000). City of walls: Crime, segregation, and citizenship in São Paulo. Berkeley: University of California.

Calderón, Verónica. (2014). Un grupo de encapuchados prende fuego a una alcaldía en el suroeste de México. El País, Jan. 14, 2014.

Cano, Arturo. (2014). Hipólito Mora se alzó en armas por los abusos de templarios contra los limoneros. La Jornada. Jan. 31, 2014.

Cano, Luis Carlos. (2009). Surge presunto grupo armado en Chihuahua. El Universal. 
Carey, Sabine, C., Neil J. Mitchell, and Will Lowe. (2013). States, the security sector, and the monopoloy of violence: A new database on pro-government militias. Journal of Peace Research 50 (2): 249-258.

Carreras, Miguel. (2013). The impact of criminal violence on regime legitimacy in Latin America. Latin American Research Review 48 (3): 85-107.

Carrión Enviada, Lydiette. (2014.) A punta de fuego toman Nueva Italia. El Universal. Jan. $13,2014$.

Casey, Nicholas. (2013). Mexico's masked vigilantes defy drug gangs - and the law. Wall Street Journal, Feb. 1, 2013.

Cederman, Lars-Erik, Kristian Gleditsch, and Halvard Buhaug. (2013). Inequality, grievances, and civil war. Cambridge: Cambridge University Press.

Chouza, Paula. (2014). Fundadores de las autodefensas impulsan un movimiento nacional. El País, May 29, 2014.

Collier, Paul, Anke Hoeffler, and Dominic Rohner. (2009). Beyond greed and grievance: feasibility and civil war. Oxford Economic Papers 61 (1): 1-27.

Conaway, Jessica. (2004). Reversion back to a state of nature in the United States southern borderlands: A look at potential causes of action to curb vigilante activity on the United States/Mexico border. Mercer Law Review no. 56:1419.

Covarrubias, Adriana. (2013). Fuerza civil mata a tiros a presunto criminal. El Universal. Feb. 21, 2013.

Covarrubias, Adriana. (2013b). Marchan policías civiles en Guerrero; exigen paz. El Universal. Sept. 3, 2013.

Covarrubias, Adriana, and Juan Cervantes. (2013). Ilegal, justicia a propia mano: SG a autodefensas. El Universal. January 25, 2013.

Dempsey, John S. (2008). Introduction to private security. Belmont, CA: Thomson Wadsworth.

Egui Brito, Verónica. (2014). Autodefensas en Michoacán surgen por fragilidad estatal. El Universal. Feb. 1, 2014.

El Universal. (2013). Gobierno mexicano apelará al diálogo ante grupos de autodefensa. El Universal, Feb. 26, 2013.

Enríquez Acosta, Jesús Ángel. (2007). Ciudades de muros. Los fracctionamientos cerrados en la frontera noroeste de México. Scripta Nova 11 (230) [no page numbers]. http://www.ub.edu/geocrit/sn/sn-230.htm

Fausset, Richard. (2014). Mexico's Geurrero state teeters on the edge of chaos. Los Angeles Times. Feb. 16, 2014.

Fearon, James D., and David D. Laitin. (2003). Ethnicity, insurgency, and civil war. American Political Science Review no. 97 (1):75-90.

Fuentes, David. (2014). Incrementa justicia de propia mano. El Universal, Aug. 17, 2014.

Fuentes Díaz, Antonio, and Guillermo Paleta Pérez. (2015). Violencia y autodefensas comunitarias en Michoacán, México. Íconos. Revista de Sciencias Sociales 19 (53): 171-186.

Gallagher, Janice. (2012). Mobilization in México in 2012: The movement for peace and the struggle for justice. Anuari del Conflicte Social. 1235-1260.

Gandaria, Manrique. (2013). Injusticia e impunidad originan grupos de autodefensa: CNDH. El Sol de México, March 13, 2013.

García Davish, Francisco. (2014). Las 'autodefensas' toman Parácuaro. Milenio. January 5, 2014. 
Gil Olmos, José. (2013). Autodefensas de Tierra Caliente ceden retenes, pero no armas. Processo. May 23, 2013.

Godoy, Angelina Snodgrass (2006). Popular injustice: Violence, community, and law in Latin America. Stanford, CA: Stanford University Press.

Goldstein, Daniel, Gloria Acha, Eric Hinojosa, and Theo Troncken. (2007). La mano dura and the violence of civil society in Bolivia. Social Analysis no. 51 (2):43-63.

Gore, Charles, and David Pratten. (2003). The politics of plunder: The rhetorics of order and disorder in southern Nigeria. African Affairs no. 102:211-240.

Grayson, George W. (2011). Threat posed by mounting vigilantism in Mexico. Strategic Studies Institute.

Grillo, Ioan. (2009). Vigilante justice spreads across Mexico. Global Post, Oct. 28, 2009.

Guerra, Edgar. (2016). Organización armada. La dimámica operatva de los grupos de autodefensa tepalcatepenses. Manuscript. Aguascalientes, Mexico: CIDE Región Centro.

Gurr, Ted Robert. (1970). Why men rebel. Princeton, NJ: Princeton University Press.

Handy, Jim. (2004). Chicken thieves, witches, and judges: Vigilante justice and customary law in Guatemala. Journal of Latin American Studies no. 36 (3):533-561.

Human Rights Watch. (1996). Colombia's killer networks: The military-paramilitary partnership and the United States. New York: Human Rights Watch.

Ibrahim, Mohammed. (2005). An empirical survey of children and youth in organised armed violence in Nigeria: Egbesu Boys, OPC and Bakassi Boys as a case study. Report for Children in Organised Armed Violence series. May 30, 2005.

Iliff, Laurence. (2008). Crime fears drive Mexicans' increase of extreme security measures. Dallas Morning News. August 29, 2008.

International Crisis Group. (2013). Justice at the barrel of a gun: Vigilante militias in Mexico. In Latin American Briefing. Mexico City/Bogotá/Brussels: International Crisis Group.

Honorine, Solenn. (2013). South Africa sees increase in vigilantism. Voice of America. Feb. 18.

Johnston, Les. (1996). What is vigilantism? British Journal of Criminology no. 36 (2):220236.

Kalyvas, Stathis N. (2015). How civil wars help explain organized crime-and how they do not. Journal of Conflict Resolution 59 (8): 1517-1540.

Kitchens, John W. (1967). Some considerations on the rurales of Porfirian Mexico. Journal of Inter-American Studies no. 9 (3):441-455.

Kowalewski, David. (1990). Vigilante counterinsurgency and human rights in the Philippines: A statistical analysis. Human Rights Quarterly 12 (2): 246-264.

Landman, Todd, and Marco Larizza. (2009). Inequality and human rights: who controls what, when, and how. International Studies Quarterly 53 (3): 715-736.

La Jornada. (2013). Incursionan grupos de autodefensa en 4 comunidades de Apatzingán y Tancítaro. La Jornada. Nov. 28, 2013.

Lichbach, Mark Irving. (1995). The rebel's dilemma. Ann Arbor: University of Michigan Press.

Macías, Verónica. (2014). En Michoacán operan tres tipos differentes de paramilitares. El Economista. Jan.16, 2014.

Mares, Isabela, and Didac Queralt. (2015). The non-democratic origins of income taxation. Comparative Political Studies 48 (14): 1974-2009. 
Martínez, Marco Antonio. (2013). Expertos dicen que grupos de autodefensa muestran debilidad del Estado, y son 'una bomba de tiempo.' SinEmbargo, Dec. 4, 2013.

Martínez, Dalia. (2014). 'Policía civil' toma Parácuaro; reportan accidente de líder. El Universal, Jan. 5, 2014.

Martínez Elorriaga, Ernesto. (2011). Se comprometen autoridades purépechas a retirar paulatinamente barricadas en Cherán. La Jornada, June 16, 2011, 19.

Martínez Elorriaga, Ernesto, and Sergio Ocampo Arista. (2013). Emboscan patrulla de la PF en Michoacán. La Jornada. July 15, 2013.

Mayorga, Juan Pablo. (2014). Las autodefensas festejan un año de su 'revolución' con misa y birria. CNN. Feb. 12, 2014.

McDonald, William F. (1977). The role of the victim in America. In Assessing the criminal: Restitution, retribution, and the legal process, ed. Randy E. Barnett and John Hagel III, 295-307. Cambridge, MA: Ballinger.

Mercado, Angélica. (2014). Cártel de Jalisco entregó a autodefensas: PGR. Milenio. Jan. 30, 2014.

Milenio. (2014). Quiénes son los líderes de las autodefensas. Milenio. Feb. 12, 2014.

Montaño, Ma. Teresa. (2013). Pretenden crear 'policías comunitarias' en sur de Edomex. El Universal, Feb. 13, 2013.

Muédano, Marcos. (2014). Suman 500 miembros de autodefensas regularizados. El Universal. Feb. 3, 2014.

Newman, Benjamin J., Christopher D. Johnston, and Patrick L. Lown. (2015). False consciousness or class awareness? Local income inequality, personal economic position, and belief in American meritocracy. American Political Science Review 59 (2): 326-340.

O’Malley, Pat, and Darren Palmer. (1996). Post-Keynesian policing. Economy and Society 25 (2): 137-155.

Omeje, Kenneth. (2005). The Egbesu and Bakassi Boys: African spiritism and the mystical re-traditionalization of security. In Civil militia: Africa's intractable security menace, edited by David J. Francis. Burlington, VT: Ashgate.

Osorio, Javier, Livia I. Schubiger, and Michael Weintraub. (2015). Vigilante mobilization and local order: Evidence from Mexico. Manuscript. Aug. 20, 2015.

Pachico, Elyssa. (2013). 98\% of Mexico's 2012 murder cases unsolved. InSight Crime. July $17,2013$.

Petrich, Blanche. (2011). Informó cónsul de EU sobre paramilitares en Ciudad Juárez: 'El Ejército se siente cómodo al dejar que cárteles hagan la guerra." La Jornada. March $16,2011$.

Phillips, Brian J. (2015). How does leadership decapitation affect violence? The case of drug trafficking organizations in Mexico. Journal of Politics 77 (2): 324-336.

Prados, Luis. (2013). Guerra de pobres en Tierra Caliente. El País, May 19, 2013.

Pratten, David, and Atreyee Sen. (2008). Global vigilantes. London: Hurst.

Provost, Claire. (2014). Gated communities fuel Blade Runner dystopia and 'profound unhappiness.' The Guardian. May 2, 2014.

Ramsey, Geoffrey. (2011). Cable suggests Mexican army may have worked with Juarez paramilitary group. Insight Crime. March 28, 2011.

Reames, Benjamin Nelson. (2007). Neofeudal aspects of Brazilian public security. In Comparative policing: The struggle for democratization, eds. M.R. Haberfeld and Ibrahim Cerrah. Los Angeles: SAGE. 
Rojo Mendoza, Reynaldo T. (2015). Frontier justice: Public support for vigilantism in Mexico's drug war. Presented at the annual meeting of the Midwest Political Science Association. April 17, 2015.

Romero, Mauricio. (2003). Paramilitares y autodefensas 1982-2003. Bogotá: Universidad Nacional de Colombia.

Rosenbaum, H. Jon, and Peter C. Sederberg. (1970). Vigilantism: An analysis of establishment violence. Comparative Politics no. 6 (4):541-570.

SDP Noticias. (2011). Aumenta 40\% demanda de servicios de seguridad privada en México por violencia. Dec. 16, 2011.

Salgado, Juan. (2013). Policías comunitarias y grupos de autodefensa: Muy diferentes. La Jornada. May 18, 2013.

Schuberth, Moritz. (2015). The challenge of community-based armed groups: Towards a conceptualization of militias, gangs, and vigilantes. Contemporary Security Policy 36 (2): 296-320.

Small Arms Survey. (2011). Small arms survey 2011: States of security. Cambridge: Cambridge University Press.

Smith, Daniel Jordan. (2004). The Bakassi Boys: Vigilantism, violence, and political imagination in Nigeria. Cultural Anthropology no. 19 (3):429-455.

Snyder, Richard. (2001). "Scaling Down: The Subnational Comparative Method." Studies in Comparative and International Development 36 (1): 93-110.

Transparency International. (2013). Global corruption barometer 2013.

Trelles, Alejandro, and Miguel Carreras. (2012). Bullets and votes: Violence and electoral participation in Mexico. Journal of Politics in Latin America 4 (2): 89-123.

Uildriks, Niels, and Nelia Tello Peón. (2010). Mexico's unrule of law: Implementing human rights in police and judicial reform under democratization. New York: Lexington.

Ungar, Mark. (2007). The privatization of citizen security in Latin America: From elite guards to neighborhood vigilantes. Social Justice no. 34 (3/4):109-110.

United Nations Development Program. (2013). Citizen security with a human face: Evidence and proposals for Latin America. In Regional Human Development Report 2013-2014.

U.S. Department of State. (2005). Honduras 2004 country report on human rights practices. Feb. 28, 2005.

Vilalta, Carlos J. (2013). Towards an understanding of community organization against crime: The case of Ciudad Juarez, Mexico. Stability: International Journal of Security and Development 2 (1): 1-15.

Walter, Matthew. (2011). US boosts funds to fight Central American drug crime. Christian Science Monitor, June 24, 2011.

Washington Valdez, Diana. (2011). Wikileaks: Juárez businessmen hired Zetas to protect themselves, cable says. El Paso Times. March 16, 2011.

Wilson, James Q. (1973). Political organizations. New York, NY: Basic Books.

Yagoub, Mimi. (2014). Mexico vigilantes financed by U.S. residents amid renewed violence. Insight Crime. Feb. 7, 2014.

Zizumbo-Colunga, Daniel. (2010). Explaining support for vigilante justice in Mexico. AmericasBarometer Insights 39, 1-12.

Zorn, Christopher. (2006). Comparing GEE and robust standard errors for conditionally dependent data. Political Research Quarterly no. 59 (3):329-341.

Zurita Eraña, Humberto. (2014). Autodefensas y estado de derecho. Milenio, Jan. 11, 2014. 